\title{
MANAJEMEN STRATEGI PENGEMBANGAN OBJEK WISATA DAERAH
}

\author{
Ernawaty \\ FISIP Universitas Riau, Kampus Bina Widya Km. 12,5 Simpang Baru Panam, Pekanbaru 28293
}

\begin{abstract}
Management of Development Strategies for Regional Tourism Objects. Bengkalis Regency's natural potential is still quite good, peat swamp forests, beaches and small islands as well as the potential of native Malay tribes are the main attraction for visitors. One of the famous natural potentials in Bengkalis Regency is the tourist beach of Rhu Bay Rupat Island. One of the attractions found in North Rupat District is Enchantment Beach. Pantai Pesona North Rupat District is the name given by the community of North Rupat District, Bengkalis Regency, Riau Province. This beach used to have different names according to the names of the residents of each village namely Tanjung Lapin Beach, Tanjung Rhu Beach and Tanjung Punak Beach. The theoretical concept used in this study is George R Terry in Manullang, which is seen from the management function, namely planning, organizing, directing, and controlling. This research method is descriptive qualitative, the technique of collecting data with interviews, observation, and documentation. The results showed that there were inhibiting factors in the development of the tourist attraction of Pesona Beach North Rupat Subdistrict, Bengkalis Regency, namely funding or budget factors, human resources, facilities and infrastructure, until now the Pesona Beach tourism object had not been able to contribute PAD to the region.
\end{abstract}

\begin{abstract}
Abstrak: Manajemen Strategi Pengembangan Objek Wisata Daerah. Potensi alam Kabupaten Bengkalis yang masih cukup baik, hutan rawa gambut, pantai dan pulau kecil serta potensi suku melayu asli merupakan daya tarik tersendiri bagi pengunjung. Salah satu dari potensi alam yang terkenal di Kabupaten Bengkalis adalah wisata pantai Teluk Rhu Pulau Rupat. Salah satu objek wisata yang terdapat di Kecamatan Rupat Utara yakni Pantai Pesona. Pantai Pesona Kecamatan Rupat Utara adalah nama yang diberikan masyarakat Kecamatan Rupat Utara Kabupaten Bengkalis Provinsi Riau. Pantai ini dahulunya memiliki nama yang berbeda-beda sesuai penamaan dari warga masing-masing desa yaitu Pantai Tanjung Lapin, Pantai Tanjung Rhu maupun Pantai Tanjung Punak. Konsep teori yang digunakan pada penelitian ini adalah George R Terry dalam Manullang, yakni dilihat dari fungsi manajemen, yaitu perencanaan, pengorganisasian, pengarahan, dan pengawasan. Metode penelitian ini bersifat deskriptif kualitatif, teknik pengum-pulan data dengan wawancara, observasi, dan dokumentasi. Hasil penelitian menunjukkan bahwa terdapat faktor penghambat dalam pengembangan objek wisata Pantai Pesona Kecamatan Rupat Utara Kebupaten Bengkalis yakni faktor dana atau anggaran, sumber daya manusia (SDM), sarana dan prasarana, sampai saat ini objek wisata Pantai Pesona belum dapat memberikan kontribusi PAD terhadap daerah.
\end{abstract}

Kata Kunci: manajemen strategi, Pantai Pesona, objek wisata

\section{PENDAHULUAN}

Pariwisata sekarang ini telah menjadi kebutuhan bagi masyarakat di berbagai lapisan, bukan hanya untuk kalangan tertentu saja. Sehingga dalam penanganannya harus dilakukan dengan serius dan melibatkan pihak-pihak terkait. Selain itu untuk mencapai semua tujuan pengembangan pariwisata harus diadakan promosi agar potensi dan daya tarik wisata dapat lebih dikenal dan mampu menggerakkan calon wisata untuk mengunjungi dan menikmati tempat wisata. Dalam hal ini industri pariwisata berlomba-lomba untuk menciptakan produk pariwisata yang lebih bervariasi menyangkut pelestarian dari objek wisata itu sendiri sesuai dengan tujuan dan pembangunan pariwisata yaitu untuk mengenalkan keindahan alam, sejarah, budaya, dan adat istiadat yang beraneka ragam.

Presiden Republik Indonesia telah menetapkan Peraturan Presiden nomor 64 tahun 2014 tentang Koordinasi strategis lintas sektor penyelenggaraan kepariwisataan yang diundangkan pada tanggal 4 Juli 2014, dijelaskan bahwa kepariwisataan bertujuan untuk menggalakkan perekonomian nasional dan daerah. Pengembangan pariwisata dapat berfungsi sebagai pembangunan yang berwawasan lingkungan dan sebagai penyeimbang ekonomi daerah. Pariwisata memiliki peranan yang sangat potensial dan strategis dalam pembangunan daerah. 
Pariwisata merupakan salah satu sektor pembangunan yang mendapat perhatian pemerintah untuk terus dikembangkan, karena sektor ini dinilai cukup berpotensi bagi perkembangan perekonomian rakyat dan penghasil devisa negara dari komoditi non migas. Potensi ini didasarkan atas beberapa faktor pendukung seperti posisi geografis, dan keindahan alam serta kekhasan sosial budaya masyarakat sebagai unsur daya tarik utama wisatawan juga merupakan modal utama dalam pengembangan sektor pariwisata. Oleh karenanya pengembangan pariwisata suatu daerah menjadi alasan utama, sebagai salah satu upaya meningkatkan pendapatan daerah melalui pemanfaatan potensi-potensi daerah. Hal ini dapat menumbuhkan industri pariwisata dan jasa, serta berdampak bagi perekonomian masyarakat yang melibatkan banyak tenaga kerja. Selain itu juga dapat membantu pembangunan daerah-daerah terpencil.

Pengembangan suatu objek wisata yang direncanakan dengan baik dapat memberikan keuntungan ekonomi untuk memperbaiki kualitas dan pola hidup masyarakat setempat, juga dapat meningkatkan pemeliharaan lingkungan yang lebih baik. Hal ini sangat membutuhkan dukungan penuh dari Pemerintah maupun partisipasi dari masyarakat.

Kepariwisataan merupakan bagian dari pembangunan nasional yang dilakukan secara sistematis, terencana, terpadu dan berkelanjutan, dengan memberikan perlindungan terhadap nilai-nilai agama, budaya yang hidup dalam masyarakat, kelestarian dan mutu lingkungan hidup serta kepentingan nasional.

Bengkalis merupakan salah satu Kabupaten di Provinsi Riau yang memiliki posisi strategis dalam pengembangan pariwisata pantai, karena berhadapan langsung dengan pelayaran internasional, yaitu selat malaka dan berada dalam segi tiga pertumbuhan, yakni segi tiga pertumbuhan Indonesia, Malaysia, Singapura, Thailand. Potensi alam Kabuipaten Bengkalis cukup baik, hutan rawa gambut, pantai dan pulau kecil serta potensi penduduk suku melayu asli merupakan daya tarik tersendiri bagi pengunjung.
Salah satu dari potensi alam yang ada di Kabupaten Bengkalis adalah objek wisata Pantai Pesona di Kecamatan Pulau Rupat Utara. Pulau Rupat merupakan salah satu pulau yang berada di Kabupaten Bengkalis yang memiliki luas sekitar 152.000 hektar, berhadapan langsung dengan Selat Malaka dan Malaysia. Terdapat dua kecamatan di Pulau Rupat, yakni Kecamatan Pulau Rupat dan Kecamatan Rupat Utara.

Kecamatan Rupat Utara memiliki potensi wisata dengan pantai pasir yang sangat indah sehingga disebut Pantai Pesona Pulau Rupat Utara. Pantai ini memanjang dari timur ke barat, merupakan daerah unggulan wisata dalam Master Plan Pariwisata Nasional untuk Provinsi Riau.

\section{METODE}

Desain penelitian ini dilakukan dengan metode observasi, wawancara, pengisian kuisioner oleh responden, dan studi literatur. Penelitian ini dilakukan di Kecamatan Rupat Utara Kabupaten Bengkalis, dan stakeholder yang terlibat pada penelitian ini adalah Kepala Dinas Kebudayaan, Pariwisata, Pemuda dan Olahraga Kabupaten Bengkalis, Kepala Bidang Pengembangan Pariwisata Kabupaten Bengkalis, Kepala Seksi Pengembangan Objek Wisata, Kepala UPT Pariwisata Kecamatan Rupat Utara. Analisis data bersifat deskriptif kualitatif.

\section{HASIL DAN PEMBAHASAN}

Pengembangan Objek Wisata Pantai Pesona akan mendorongnya terjadi peningkatan pendapatan masyarakat yang pada gilirannya akan mendorong peningkatan kesejahteraan masyarakat. Seiring dengan itu, pengembangan objek wisata Pantai Pesona secara langsung atau tidak langsung akan mendorong pertumbuhan dan pengembang wilayah, baik secara fisik, maupun secara sosial, budaya dan ekonomi pada Kecamatan Rupat Utara.

Objek wisata Pantai Pesona dapat ditempuh dengan menggunakan transportasi speedboat, kapal ferry dan penyeberangan Roro. Jarak tempuh 20 menit dengan speed- 
boat, 45 menit menggunakan kapal ferry, dan 1 jam menggunakan penyeberangan Roro. Jernihnya warna air laut Pantai Pesona ini menambah pesona pantai tersebut, oleh karenanya pantai ini perlu dikembangkan oleh Dinas Pariwisata,

Pantai Pesona ini setiap tahunnya menampilkan budaya tarian seperti Tari Zapin, permainan Gasing yang dilakukan diatas bara api pada malam hari. Suku yang berada di daerah ini dikenal dengan nama suku Akit, juga adanya acara mandi Safar yang sudah ada sejak puluhan tahun yang diadakan pada hari rabu tepatnya di minggu keempat bulan Safar. Mandi Safar ini bertujuan untuk menolak bala atau bencana, juga merupakan hari pertemuan bujang dan dara ditandai dengan digelarnya Joget Lambak atau sering disebut Serampang Laut.

Indikator yang digunakan pada penelitian ini untuk mengukur strategi pengembangan objek wisata pantai pesona Kecamatan Rupat Utara Kabupaten Bengkalis adalah konsep G.R. Terry dalam Manullang, yaitu dengan indikator planning (perencanaan), organizing (pengorganisasian), actuating (pengarahan), dan controlling (pengawasan). Berikut akan diurai masing-masing indikator.

a. Planning (perencanaan), kurang optimal yakni penyusunan rencana kerja dalam manajemen strategi pengembangan objek wisata Pantai Pesona Kecamatan Rupat Utara Kabupaten Bengkalis kurang sesuai dengan kebijakan yang telah dibuat, kurang sesuai dengan sasaran dan tujuan yang telah direncanakan.

b. Organizing (pengorganisasian), kurang jelasnya perincian kerja antara pihak Dinas Kebudayaan, Pariwisata, Pemuda dan Olahraga Kabupaten Bengkalis dengan pihak UPT sebagai pengelola/pengembang objek wisata Pantai Pesona Kecamatan Rupat Utara Kabupaten Bengkalis, termasuk penempatan dan pembagian tugas masingmasing pihak Dinas Kebudayaan, Pariwisata, Pemuda dan Olahraga Kabupaten Bengkalis dengan UPT Pariwisata.

c. Actuating (pengarahan), tidak adanya pe- doman kerja dalam manajemen strategi pengembangan objek wisata Pantai Pesona Kecamatan Rupat Utara Kabupaten Bengkalis, tidak adanya pengarahan bagi pihakpihak terkait dan kurangnya koordinasi antara Instansi terkait seperti Dinas Pekerjaan Umum (PU), pihak Kecamatan Rupat Utara, pihak UPT Pariwisata, Kepala Desa, dan RT/RW setempat.

d. Controlling (pengawasan), kurang optimal yakni tidak adanya standar yang jelas dalam melakukan pengawasan, kurangnya melakukan penilaian dan tindakan perbaikan yang dilakukan kurang jelas, termasuk sanksi yang diberikan tidak jelas.

Faktor-faktor yang mempengaruhi manajemen strategi Dinas Pariwisata dalam pengembangan objek wisata Pantai Pesona di Kecamatan Rupat Utara Kabupaten Bengkalis adalah sebagai berikut:

a. Anggaran/Dana

Minimnya anggaran/dana adalah merupakan faktor yang mempengaruhi manajemen strategi Dinas Pariwisata dalam pengembangan objek wisata Pantai Pesona di Kecamatan Rupat Utara Kabupaten Bengkalis, dana yang diharapkan dari APBD tidak mencukupi, sehingga anggaran/dana diambil dari proyek yang berkaitan dengan kepariwisataan.

b. Sumber Daya Manusia (SDM)

Rendahnya tingkat pendidikan pihak pengelola/pengembang objek wisata Pantai Pesona Kecamatan Rupat Utara Kabupaten Bengkalis, berpengaruh terhadap pengembangan objek wisata itu sendiri. Rata-rata tingkat pendidikan pihak pengelola/pengembang objek wisata tamat SMA (Sekolah Menengah Atas).

c. Sarana dan Prasarana

Kurangnya sarana dan prasarana juga berpengaruh terhadap manajemen strategi Dinas Pariwisata dalam pengembangan objek wisata Pantai Pesona Kecamatan Rupat Utara Kabupaten Bengkalis. Sarana prasarana yang dimaksud adalah: tidak adanya penginapan, rumah makan, jasa kesehatan, rumah ibadah dan MCK (Mandi Cuci Kakus). 


\section{SIMPULAN}

Pariwisata memiliki peranan yang sangat potensial dan strategis dalam pembangunan daerah. Bengkalis merupakan salah satu Kabupaten di Propinsi Riau yang memiliki posisi strategis dalam pengembangan pariwisata pantai karena berhadapan langsung dengan pelayaran internasional, yaitu Selat Malaka dan berada dalam kawasan segitiga pertumbuhan, yakni segitiga pertumbuhan Indonesia - Malaysia - Singapura dan Indonesia Malaysia - Thailand.

Pengembangan pariwisata Pantai Pesona Kecamatan Rupat Utara Kabupaten Bengkalis belum maksimal. Hal ini terlihat dari indikator penelitian yaitu Planning, Organizing, Actuating dan Controlling. Adapun faktor-faktor yang mempengaruhi adalah anggaran/dana, kurangnya sumber daya manusia (SDM), dan kurangnya sarana dan prasarana/infrastruktur seperti jalan menuju lokasi rusak dan berlobang, kurangnya penginapan, rumah makan, restoran, dan hotel tempat wisatawan asing, terbatasnya anggaran dari pihak pemerintah untuk mengembangkan objek wisata tersebut.

\section{DAFTAR RUJUKAN}

Akdon, 2009. Strategic Management For Education Management. Bandung: Alfabeta

Allison M, Kaye J, 2005. Perencanaan Strategis Bagi Organisasi Nirlaba. Jakarta: Yayasan Obor Indonesia Bagyono. 2010. Manajemen Strategik
Keorganisasian Publik. Bandung: Rafika Aditama

Hasibuan, Malayu S.P. 2005. Manajemen, Dasar Pengertian dan Masalah. Jakarta: Bumi Aksara

Hugest. 2005. Manajemen Strategi. Bandung:

Rekayasa Sains

J, Salusu. 2004. Pengambilan Keputusan Strategic Untuk Organisasi Publik dan Organisasi Non Profit. Jakarta: Grasindo Widiasarana Indonesia

Kuncoro, Mudrajad. 2005. Strategi Bagimana Keunggulan Kompetitif. Jakarta: Erlangga.

Manullang, 2011. Dasar-dasar Manajemen, Jakarta: Ghalia Indonesia

Nawawi H, 2012. Manajemen Strategik Organisasi Non ProfitBidang Pemerintahan.

Gajah Mada University Press, Yogyakarta

Nilasari Senja, 2014. Manajemen Strategi itu Gampang. Jakarta: Dunia Cerdas

Pendit, Nyoman S. 2009. Ilmu Pariwisata Sebuah Pengantar Perdana. Jakarta: Pradnya Paramita

Rankuti, Freddy. 2006. Analisis SWOT Teknik Perbedaan Kasus Bisbis. Jakarta: Gramedia Pustaka Utama

Stoner, James A.F. 1992. Manajemen, Jakarta: Erlangga

Sumarno. 2008. Dasar-dasar Pariwisata. Yogyakarta: Andi

Ulbert, Silalahi. 2002. Pemahaman Praktis Asas-asas Manajemen. Bandung: Mandar Maju. 